\title{
Farklı Partikül Boyutlarındaki Enginar Lifi İlavesinin Köfte Kalitesi Üzerine Etkisi
}

\author{
Hülya Atasoy ${ }^{1}$, Kübra Özkan $^{1}$, Ayşe Karadağ $^{1 *}$, Osman Sağdıç $^{1}$ \\ ${ }^{1}$ Yıldız Teknik Üniversitesi, Kimya Meteraluji Fakültesi, Gıda Mühendisliği, 34210, İstanbul, Türkiye (ORCID: 0000-0002-0321-355X; 0000-0003-0580-5804; 0000-
} 0001-8615-7321; 0000-0002-2063-1462)

(İlk Geliş Tarihi 25 Mayıs 2019 ve Kabul Tarihi 1 Haziran 2019)

(DOI: $10.31590 /$ ejosat.544132)

\begin{abstract}
ATIF/REFERENCE: Atasoy, H., Özkan, K., Karadağ, A., \& Sağdıç, O. (2019). Farklı Partikül Boyutlarındaki Enginar Lifi İlavesinin Köfte Kalitesi Üzerine Etkisi. Avrupa Bilim ve Teknoloji Dergisi, (16), 275-282.

$\ddot{O} \mathbf{z}$

Enginar sebzesi işleme tesislerinde, tüm bitkinin yaklaşık \% 70’i, yaprak, sap, çiçek gibi kısımları katı atık olarak açığa çıkmaktadır. Bu atıklar genellikle hayvan yemi üretiminde ya da gübre amacıyla kullanılmaktadır. Ancak, içerdiği zengin lif miktarı açısından bu atık kısmının, diyet lifi olarak kullanılması potansiyeli mevcuttur. Çalışmamızda, enginar atıklarından elde edilen lif, \%3.38 protein, \%0.34 yağ, \%90 toplam diyet lif ve $6.98 \mathrm{pH}$ değerine sahiptir. Üretilen enginar lifi, boyutun fizikokimyasal özellikler üzerine etkilerini incelemek için iki farklı boyutta $(150$ ve $450 \mu \mathrm{m})$ hazırlanmıştır. Lifin, su ve yağ bağlama kapasitesinin partikül boyutunun azalması ile birlikte azaldığı gözlenmiştir. Köfte örneklerine, iki farklı konsantrasyonda ve iki farklı boyutta eklenen enginar lifinin, örneklerin fiziksel, kimyasal, tekstürel ve duyusal özellikleri üzerine etkisi incelenmiş ve ayrıca sonuçlar, lif eklenmeyen kontrol köfte örnekleri ile karşılaştırılmıştır. Köfte örneklerinde, ağırlık kaybındaki azalmaya eklenen lifin miktarının etkisi, lifin boyutuna göre farklılık göstermiştir. Düşük boyutlu ve az miktarda lif eklenen örnek hariç, kontrol örneğindeki ağırlık kaybı, lif eklenen örneklerden daha fazla olmuştur. Çapta azalma üzerine ise, lif miktarının etkisi tek başına önemli olmazken; lif boyutunun etkisi ise, eklenen lifin miktarına göre farklılık göstermiştir. Çapta azalmanın büyük boyutlu lif kullanıldığı zaman daha az olduğu, ancak köftedeki lif miktarının arttırılmasıyla bu etkinin kontrole göre önemli olmadığı görülmüştür. Pişmemiş köftelerin sertlik değeri üzerinde, lif miktarının etkisi yalnızca büyük boyutlu lif eklenen örneklerde gözlenmiş, ancak pişirme sonrası bu farklılık da önemli olmamıştır. Yapışkanlık değeri açısından, pişmemiş köftelerde lif miktarı ve boyutla interaksiyonu önemli olmuştur, yapışkanlık değeri düşük boyutlu lif kullanımında lif miktarı arttıkça azalmış, ancak yüksek boyutlu lif kullanıldığı zaman miktarın etkisi önemli olmamıştır. Örnekler, pişirildiği zaman ise, her iki boyutta da lif miktarının artması ile yapışkanlık azalmıştır. Lif eklenenen pişmiş köfte örneklerinde duyusal ve tekstürel açıdan lif eklenmeyen kontrol köfteleri ile karşılaştırıldığ zaman, önemli düzeyde farklar belirlenmemiştir. Bu sonuçlar, diyet liflerinin sağlık açısından faydaları ve köftelerdeki olumlu etkileri göz önüne alındığında, et ürünlerinde kullanımının yaygınlaştırılabileceğini göstermektedir.
\end{abstract}

Anahtar Kelimeler: Enginar lifi, Köfte, Lif boyutu, Tekstürel değişim

\section{The effects of artichoke fiber addition with different sizes on the quality of meatballs}

\begin{abstract}
The discarded parts of globe artichoke at harvesting and after industrial processing consist of leaves, stems, and bracts. Those byproducts can represent up to $70 \%$ by weight of the total biomass, are disposed of as waste. Generally, they are used for composting or in some cased as animal feed. Due to the high fiber content, they carry enormous potential as a source to recover dietary fiber and added value products that can be used in the food industry. In this study, the artichoke fiber, obtained from industrial by-products, had $90 \%$ total dietary fiber, $3.38 \%$ protein, $0.34 \%$ fat content with a $\mathrm{pH}$ value of 6.98 . Artichoke fiber with two different particles size (150 and
\end{abstract}

\footnotetext{
* Sorumlu Yazar: Yıldız Teknik Üniversitesi, Kimya Meteraluji Fakültesi, Gıda Mühendisliği, İstanbul (ORCID: 0000-0001-8615-7321), karadaga@yildiz.edu.tr
} 
$450 \mu \mathrm{m}$ ) was used to evaluate the effects of size on physicochemical properties. Water and oil holding capacities of fiber were reduced by the decrease in the particle size. Artichoke fiber with two different sizes at two different concentration was added to meatballs, and the change in physical, chemical, textural and sensory properties was determined, and they were compared to the control meatballs that have no fiber in its formulation. The weight loss reduction in meatballs differed with the addition of fiber depending on its particle size. The weight loss in the control sample was higher than the fiber added meatballs except for the sample prepared by less amount of fiber with a smaller particle size. The amount of fiber by itself was not found as significant on the meatball size, however, its interaction with particle size was important. The reduction of meatball size was lower when fiber with larger particle size was added, yet increasing the amount of fiber this difference was not important compared to the control meatballs. The effects of fiber addition on the hardness values of uncooked meatballs were observed only when larger size fiber was added, however, this difference was lost after cooking. The amount of fiber and its interaction with size was important on the stickiness value of uncooked meatballs, it was decreased when smaller fiber particles added at higher concentration, but when larger fiber particles were added the fiber concentration was not important. When the meatballs were cooked, the stickiness was reduced by increasing the fiber concentration at both particle size. Compare to the control meatballs, the cooked meatballs with added fiber did not show important differences in terms of textural and sensory properties. Therefore considering the health benefits of having dietary fibers in the formulation, and quality of meatballs added with fiber, the artichoke fibers can be used in meat products as functional food additives.

Keywords: Artichoke fiber, Meatball, Particle size, Textural Properties

\section{Giriş}

Bugüne kadar yapılan araştırmalar; lif alımının obezite, kardiyovasküler hastalıklar, kolon kanseri ve diğer bazı kronik hastalıkların risklerini azaltarak daha sağlıklı bir yaşam tarzını desteklediği ortaya koymaktadır (Verma, \& Banerjee, 2010). Diyet lifi, insan sağlığı ve ürün kalitesi üzerine olumlu etkilerine bağlı olarak önemli bir gıda bileşenidir. Ayrıca diyet lifleri gida ürünlerinde su tutma kapasitesi, yağ bağlama kapasitesi, emülsifikasyon ve jel oluşumu gibi bazı fonksiyonel özellikleri arttırmak için kullanılmaktadır (Elleuch ve ark., 2011). Tekstür özelliklerini modifiye edebilir, pişirme verimliliğini arttırabilir, yağ ikame maddesi olarak da kullanılabilirler (Choi ve ark., 2010 ve Fernandez-Lopez ve ark., 2010).

Enginar, diyet lif bakımndan zengin ve nişasta yokluğunda polisakkarit rezervi olarak tanımlanan Compositae familyasından bir bitkidir. Taze, donuk ya da konserve gıda olarak satışı bulunan enginar bitkisinin yenilebilir kısmı ekonomik değeri olan bir sebze türüdür. Enginar sebzesi işleme tesislerinde, tüm bitkinin yaklaşık \% 70’i katı atık olarak açığa çıkmaktadır. Bu atıklar genellikle hayvan yemi üretiminde ya da gübre amacıyla doğal atık olarak kullanılmaktadır. Proses atıkları olan bu kısımların polifenoller, fruktooligosakkaritler, lifler ve mineraller gibi pekçok biyoaktif bileşenler açısından zengin içeriğe sahip olduğu belirtilmiştir (Machado ve ark., 2015). Özellikle enginarın kalbi, iyi bir lif kaynağıdır ve yüksek verimlilikle elde edilebilmektedir. Enginar bitkisi, depo organellerinde major karbonhidrat rezervi olarak inülin sentezler, biriktirir. İnülin molekülü zincir uzunluğu oldukça fazla olan, bitkilerde en yüksek polimerizasyon derecesine sahip, ve suda çözünebilen bir diyet lifidir. İnülin aynı zamanda düşük kalorili bir lif olduğundan; yağı azaltılmış gıdaların üretiminde kullanılmaya da olanak sağlamaktadır (Hellwege ve ark., 2000).

Et biyolojik değeri yüksek protein, esansiyel yağ asitleri, vitaminler ve mineral içeriği sebebiyle beslenme açısından birincil önceliğe sahiptir. Et ürünleri, yüksek oranda doymuş yağ asitleri ve kolestrol içermektedir ve diyet lif açısından fakirdir. Ayrıca, et ve et ürünlerini işleme aşamalarında, üürnlere yüksek oranda tuz ve ilave yağ ilave edilmektedir (Talukder, 2013). Sağlıklı yaşam ve düşük kalorili gıdaların üretimi için, gıda üreticileri düşük yağ içerikli et ve et ürünlerinin üretimine önem vermektedir (Kılınççeker \& Kurt, 2018). Bu amaçla, diyet lifinin düşük yăg içerikli et ve et ürünlerinde kullanımı ile, ürünlerde pişirme kayıplarını azaltma, su tutma kapasitesini arttırma, depolama stabilitesini ve tekstürel özellikleri olumlu yönde arttırma gibi hem fonksiyonel özellikler açısından iyileştirme, hem de maliyetleri düşürme gibi sonuçlar hedeflenmektedir (Ekici \& Ercoşkun, 2007).

Farklı diyet lifi kaynakları et ürünlerinde, birlikte veya tek başlarına kullanılabildikleri gibi, farklı miktarlarda ve partikül boyutlarında kullanılabilmektedir (Han \& Bertram, 2017). Bilgimiz dahilinde, enginar lifinin, geleneksel köftelere eklenmesi ile ilgili bir çalışma mevcut değildir. Bu çalışmanın amacı, farklı boyutlarda ve miktarlarda enginar lifinin geleneksel köfte ürününde kullanılması, lifin su tutma, yağ tutma kapasitelerinin belirlenmesi, köftelerdeki ağırlık ve çap değişimleri, tekstürel ve duyusal özellikleri üzerine olan etkilerinin incelenmesidir.

\section{Materyal ve Metot}

\subsection{Materyal}

Bu çalışmada köfte örnekleri, Yıldız Teknik Üniversitesi Gıda Teknolojisi Laboratuvarında üretilmiştir. Kıyma yerel bir kasaptan hijyenik şartlarda temin edilmiştir. Köfte için kullanılan kıyma, Balıkesir yöresine ait ve dananın ön kol kısmından hazırlanmıştır. Tez çalışmasında kullanılan enginar lifi, İstanbul'daki Baharot Lezzet Karışımları Gıda San. ve Tic. A.Ş.'de standart olarak üretilmiştir. 


\subsection{Metod}

\subsubsection{Enginar Lifinin Üretimi}

Balıkesir yöresinde yetişen ve konserveciliğe uygun Bayrampaşa cinsi enginar bitkisinin önce orta kısımda bulunan tablası konserve üretimi için alınmış ve sonra geriye kalan yaprak ve sap kısımları hasat süresinde toplanmış $-40^{\circ} \mathrm{C}$ de şoklandıktan sonra, $18^{\circ} \mathrm{C}$ de muhafaza edilmiştir. Üretim için, ürün $+4{ }^{\circ} \mathrm{C}$ ' ye alınıp çözündürülmüş ve mikrobiyal yükü azaltmak için dezenfektanlı su ile yıkanmıştır. Enginardaki polifenol oksidaz enziminin inaktivasyonu için $100^{\circ} \mathrm{C}$ 'de su içerisinde $9 \mathrm{dk}$ bekletilmiş ve sonra doğrayıcıdan geçirilerek parçalama işlemi gerçekleştirilmiştir. Rengin açılması ve istenmeyen bileşenlerin uzaklaştırılması için suda yıkama işlemi yapılmıştır. Fazla su presleme yapılarak uzaklaştırılmış ve akışkan yataklı firınla $100{ }^{\circ} \mathrm{C}$ 'de, son ürün nemi \% 10 'un altında olacak şekilde kurutma yapılmıştır. Kurutulmuş ürün, bıçaklı değirmende istenilen elek boyutuna göre öğütülmüş olup, 1şık ve nem geçirmeyen ambalajlar ile paketlenmiştir. Elek makinasında (Fritsch GmbH, Almanya), farklı partikül boyutlarında enginar lifleri elde edilmiştir. Titreşimli elekler ile, 150 ve $450 \mu \mathrm{m}$ boyutlu lif üretilmesi hedeflenmiş, uygun boyutlu eleklerden geçirilen ürünün boyutları, Master Sizer (Malvern Mastersizer 2000, İngiltere) cihazı ile ölçülmüsstür.

\subsubsection{Enginar Lifinde Su Tutma ve Yăg Tutma Kapasitelerinin Belirlenmesi}

Farklı boyuttaki enginar lifi örnekleri nem içeriklerinin düşürülmesi amacıyla 6 saat süreyle $100^{\circ} \mathrm{C}$ etüvde kurutulmuş ve desikatörde soğutulmuştur. Kurutulan örneklerden $50 \mathrm{ml}$ 'lik santrifüj tüpüne $1 \pm 0.01 \mathrm{~g}$ alınmış, $30 \mathrm{ml}$ distile su eklenerek 6 saat oda sicaklı̆̆ında bekletilmiş ve örnekler $14000 \mathrm{~g}$ de 1 saat santrifüj edilmiş̧ir (Thermo Scientific Heraeus, Multifuge X3 FR, Almanya). Sıvı faz tartılarak su tutma kapasitesi; örnek miktarı (g) başına tutulan su miktarı (g) olarak ifade edilmiştir. Yağ tutma kapasitesi için aynı şekilde etüvde kurutulan enginar liflerinden $50 \mathrm{ml}$ 'lik santrifüj tüpüne alınan $4 \pm 0.01 \mathrm{~g}$ örnek, $24 \mathrm{ml}$ mısır özü yağ 1 ile $30 \mathrm{dk}$ vorteks karıştırıcıda 1800 rpm'de karıştırılmıştır. Karışım 1600 g'de 25 dk santrifüjlenerek sıvı kısmın hacmi ölçülmüştür. Yağ bağlama kapasitesi, örnek miktarı (g) başına tutulan yağ miktarı (g) olarak ifade edilmiştir.

\subsubsection{Köfte Ürününün Hazırlanması ve Pişirilmesi}

Kullanılan dana kıyması \%20.89 protein, \%14.81 yağ, \%64.21 rutubet, $\% 0.88$ kül ve $5.50 \mathrm{pH}$ değerine sahiptir ve içine kütlece $\% 1.1$ tuz, $\% 0.47$ pulbiber, $\% 0.67$ tatl toz biber, $\% 0.47$ karabiber, $\% 0.07$ kekik, $\% 0.27$ kimyon, $\% 0.27$ sarımsak, $\% 0.13$ maydonoz ve \%0.6 soğandan oluşan baharat karışımı, \%3 sıvı yağ (ayçiçek yağı) ve \%15 su ilave edilerek geleneksel köfte hazırlanmıştır. Daha sonra köfte hamuruna sırasıyla \% 0.4 ve $\% 2.4$ oranlarında farklı boyutlardaki $(150 \mathrm{ve} 450 \mu \mathrm{m})$ enginar lifleri deneme noktalarına uygun şekilde karıştırılarak yarım saat el ile yoğrulmuştur. Kontrol örneği ise lif ilavesi yapılmadan diğer örneklere ilave edilen oranda sadece baharat karışımı, sıvı yağ ve su eklenerek yoğurulmuştur. Köfteler $7.5 \pm 0.5 \mathrm{~cm}$ çapında ve üniform büyüklükte ve şekillendirici aparat ile köftelerin ağırlıkları $57.5 \pm 2.5 \mathrm{~g}$ olacak şekilde ayarlanmıştır. $220{ }^{\circ} \mathrm{C}$ de önceden 1 sııtılmış firında 10 dakika olacak şekilde tüm köfteler pişirilmiştir.

\subsubsection{Köfte Örneklerinde Ă̆grlık ve Çap Belirlenmesi, pH tespiti}

Köfte örneklerinin pişirme öncesinde tartımı yapılmış, pişirme işlemi bittikten sonrasında, ağırlıkları tekrar ölçülmüştür. Çap değişimi için; aynı şekilde tüm örneklerin pişirme öncesinde çapı ölçülmüş, pişirme işlemi bittikten sonra tekrar çapı ölçülerek \% çapta küçülme hesaplanmıştır. pH tespiti için; çiğ ve pişmiş örneklerin her birinden $10 \mathrm{~g}$ tartılıp, üzerine $100 \mathrm{ml}$ distile su eklendikten sonra homojenizatörde 1 dakika homojenize edilmiştir. Standart tampon çözeltileri ile pH metre (Mettler Toledo- S230 Seven Compact, İsviçre) kalibre edildikten sonra $\mathrm{pH}$ metre elektrodu $22 \pm 2^{\circ} \mathrm{C}$ 'deki beherin içindeki numuneye direk daldırılarak ölçülmüştür.

\subsubsection{Köfte Örneklerinde Su Oranı ve Yă̆ Tayini}

Çiğ ve pişmiş köfte örneklerin her birinden $5 \mathrm{~g}$ alınıp kurutma kaplarına konulmuştur. Daha sonra kaplar, $105 \pm 2{ }^{\circ} \mathrm{C}$ 'lik etüv (Jeio Tech OF-12G Korea) içerisine yerleştirilmiş, örnekler sabit tartıma gelinceye kadar yaklaşık 20 saat kurutulmuş ve desikatörde bekletilip, tartım alınarak nem içerikleri belirlenmiștir . Örneklerdeki yağ miktarının tespitinde Soxhlet yöntemi kullanılmıştır. Çiğ ve pişmiş örneklerin her birinden 5'er g alınarak cihazın (BUCHI Extraction Unit E-816 SOX Switzerland) ekstraksiyon kartuşuna yerleştirilmiştir. Çözücü olarak dietileter ile yaklaşık 4 saat süreyle, aynı cihazda ekstrakte ve kurutma aşamalı olarak gerçekleştirilmiştir.

\subsubsection{Köfte Örneklerinde Renk ve Tekstür Profil Analizleri (TPA)}

Çiğ ve pişmiş köfte örneklerinin her biri renk ölçümleri kromametre Konica Minolta Chroma Meter CR-400, Japonya) kullanılarak belirlenmiştir. L* (açıklık-koyuluk), a* ( \pm kırmızı-yeşil) ve b* ( \pm sarı-mavi) renk koordineleri CIE Lab renk skalasına göre ve doğrudan örneklerin 3 farklı noktasından okuma yapılmıştır. Tekstür profil analizi ise; TA-HD PLUS (Stable Micro Systems Ltd., Surrey, the UK) marka TPA cihazında Alüminyum p/36R probu kullanılarak pişmiş köfte örneklerinin her bir grubunda ölçülmüştür. Sertlik, yapışkanlık, esneklik, iç yapışkanlık, sakızımsılık, elastikiyet, çiğnenebilirlik özellikleri değerlendirildi.

\subsubsection{Köfte Örneklerinde Duyusal Analiz}

Farklı konsantrasyonda ve farklı partikül boyutunda enginar lifi eklenen 4 adet köfte örneği, kontrol grubuna göre panelistler tarafindan kıyaslanmıştır. Köfte örnekleri önceden ısıtılmış $\left(220^{\circ} \mathrm{C}\right)$ elektrikli firında yaklaşık 10 dakika süre ile pişirilmiş ve ardından 
duyusal analiz gerçekleştirilmiştir. Panelistler, köftelerdeki koku, renk, tat ve aroma, sululuk, sertlik, çiğnenebilirlik ve genel beğeni özellikleri değerlendirmiştir.

\subsection{8. İstatiksel Analiz}

Köftelere iki farklı konsantrasyonda (\%0.4 ve \%2.4) ve iki farklı partikül boyutunda ( 150 ve $450 \mu \mathrm{m})$ enginar lifi eklenmiş ve özelliklerindeki değişim iki yollu ANOVA analizi ile gerçekleştirilmiştir. Ayrıca kontrol örneği ile lif eklenen örnekler arasındaki farklılık ise tek yollu ANOVA analizi ile değerlendirilmiştir. Örnekler arasındaki farklılık ise TUKEY analizi ile çoklu karşılaştırma testi ile gerçekleştirilmiş̧tir. Bu amaçla, SPSS programı (SPSS 17.0, USA) kullanılmıştır.

\section{Araştırma Sonuçları ve Tartışma}

\subsection{Farklı boyuttaki enginar liflerinin su ve yağ tutma kapasiteleri}

$465.59 \mu \mathrm{m}$ ve $153.67\left(\mathrm{D}_{4,3}\right)$ boyutlarında partikül boyutuna sahip enginar liflerinin, su tutma kapasitesi boyuttaki azalma ile beraber $\% 10.03 \pm 0.01$ 'ten $8.96 \pm 0.02$ 'ye azalırken, yağ tutma kapasitesi de $\% 4.15 \pm 0.02$ 'den $\% 3.38 \pm 0.01$ 'e azalmıştır. Benzer sonuçlar farklı hammaddelerden elde edilen liflerde gözlenmiştir. (Premavalli, 2010) kabak ve turp liflerinde, (Ye, Tao, Liu, Zou, \& Zhao, 2015) turunçgil posasından elde edilen liflerde, (Zhang ve ark., 2012) mantar liflerinde boyut azaldıkça su bağlama ve yağ tutma kapasitesinin azaldığını görmüşlerdir. Yapıları daha kaba ve iri olan büyük boyutlu partiküllerin, santrifüj işlemi sonrasında daha düşük boyutlu partiküllere göre birbirlerine daha zayıf bağlandıklarından, daha fazla su ve yağı tutabildiği belirtilmektedir. Çeşitli gıdaların vizkozite ve tekstürel özelliklerini iyileştirilmesi, sinerisisin (su salma) engellenmesi amacıyla kullanılabilmeleri ve ayrıca sindirim sonrası fekal hacmin artması ile kabızlık ve bağırsak kanseri riskinin azalmasında etkili olduğundan dolayı lif örneklerinde su bağlama kapasitesinin yüksek olması istenir.

Yağ tutma kapasitesinin yüksek olması, et ürünleri gibi gıdalarda örneğin pişme sırasında normalde kaybolan yağın üründe tutulmasını sağlayarak lezzetin arttırılmasında fayda sağlayabileceği gibi, yağ-su emülsiyonlarında stabilitenin artmasında, reolojik özelliklerin iyileştirilmesinde önem taşır. Bundan dolayı, yağı azaltılmış ürünlerde yağ yerine kısmen lif kullanılması ile ilgili son yıllarda yapılan çalışmaların sayısında artış gözlenmektedir (Tomaschunas ve ark., 2013) (Ktari, Smaoui, Trabelsi, Nasri, \& Ben Salah, 2014) (Henning, Tshalibe, \& Hoffman, 2016). Enginar lifinin yüzey alanı küçüldükçe yani lifin daha az öğ̈̈ülmesi ile su ve yağ absorbsiyonu kü̧̈ük boyutlu liflere göre daha yüksek elde edilmiştir. Yapılan bir çalışmada ise $53 \mu \mathrm{m}, 105 \mu \mathrm{m}$ ve $210 \mu \mathrm{m}$ boyutlarında havuç lifi elde edilmiş ve bu boyutlardaki liflerin su tutma kapasitesi, suda şi̧̧me kapasitesi ve tutulan suyu burakma kapasitesi saptanmıştır. Sonuç olarak, su tutma kapasitesi havuç lifi boyutunun artması ile artmışıı ve 105 ile $210 \mu \mathrm{m}$ boyutundaki liflerin su tutma kapasiteleri benzer değere sahiptir. Suda şişme kapasitesi de aynı şekilde lif boyutu arttıkça artmıştır. Tutulan suyu bırakma kapasitesi ise $53 \mu \mathrm{m}$ boyutundaki havuç lifinde en düşük değerde iken boyut artışı ile tutulan suyu bırakma kapasitesi artmaktadır (Enclada ve ark., 2015).

\subsection{Enginar lifinin köftelerin kalitesi üzerine etkileri}

\subsubsection{Köfte örneklerinin ă̆ırlıkları, çapları ve pH değerlerindeki değgişim}

Elde edilen enginar lifinin protein, yağ, diyet lif ve $\mathrm{pH}$ değerleri sırasıyla \%3.38, \%0.34, \%90 ve 6.98 şeklindedir. Köfte hazırlanmasında kullanılan dana kıyması $\% 64.21$ su, \%20.89 protein, \%14.81 protein ve \%0.88 kül içeriğine sahip olup, pH değeri 5.50 dir. Köftelere iki rafklı konsantrasyonda (\% 0.4 ve \%2.4) iki farklı partikül boyutunda (150 ve $450 \mu \mathrm{m})$ enginar lifi eklenmiş, pişirme sonrası köftelerin ağılık ve boyutundaki değişim, Tablo 1'de verilmiştir. Ayrıca kontrol örneği olarak hiç lif eklenmeyen köfteler hazırlanmış ve aynı ölçümler bu örneklerde de gerçekleştirilmiştir. İki yönlü ANOVA analizi sonuçlarına göre ağırlık kaybı üzerine lif miktarı, lif boyutu ve bu değişkenlerin interaksiyonu önemli olmaktadır $(\mathrm{p}<0.05)$, diğer bir deyişle ağıllık kaybındaki azalmaya lif miktarının etkisi, lifin boyutuna göre farklılık göstermektedir. Düşük boyutta lif eklendiği zaman, lif miktarı arttıkça ağırlık kaybındaki azalma önemli olurken, yüksek boyutta lif eklendiğinde ise lif miktarının oranı önemli olmamıştır. Kontrol örneğinin ağırlık kaybının ise düşük boyutlu ve düşük miktarda lif eklenerek hazırlanan köfteler hariç diğerlerinden daha fazla olduğu gözlenmiştir. Çap azalması üzerine ise, lif miktarının etkisi tek başına önemli değil iken, lif boyutu ve lif miktarının interaksiyonu ve lif boyutu önemlidir ( $<<0.05$ ), diğer bir deyişle çap azalmasına boyutun etkisi kullanılan lifin konsantrasyonuna göre farklılık göstermektedir. Kontrol örneğinde çapta azalmanın sadece yüksek boyutlu ve düşük miktarda lif eklenen örnekten farklı olduğu görülmektedir. Pişirme sonrası ağılık kaybı ve çapta azalma, köfte yapısından yağın ayrılması ve suyun dışarı salınması ile ilgili olduğundan, lif eklenen köftelerde bu değerler, lifin su bağlama ve yağ tutma kapasitesi ile ilişkilidir (Talukder, 2015). Lif eklenmesi ile köfte yapısı daha sıkı olmuş ve pişirme sırasında etten açığa çıkan su, lif tarafindan absorbe edildiği için çapta kü̧̈ülmeler ve ağırlık kaybı daha az görülmektedir. Örneklerimizde de, eklenen lifin miktarı arttıkça daha az ağılık kaybı gözlenmiş, ayrıca aynı lif miktarında (\%0.4) daha iri ve kaba olan büyük boyutlu lif $(450 \mu \mathrm{m})$ kullanıldığında, ağırlık kaybının kontrole ve daha küçük boyutlu life $(150 \mu \mathrm{m})$ göre daha az olduğu görülmektedir. Çapta azalmanın da yine büyük boyutlu lif kullanıldığı zaman daha az olduğu, ancak köftedeki lif miktarının artmasıyla bu etkinin kontrole göre önemli olmadığı görülmektedir.

Enginar lifinin ( $\mathrm{pH}=6.98)$ eklenmesi köftelerin $\mathrm{pH}$ değerinde artışa sebep olmuştur ve bu artış en fazla en yüksek miktarda (\%2.4) ve en büyük boyutlu $(450 \mu \mathrm{m})$ eklenen liflerle hazırlanan köftelerde gözlenmiştir. Benzer şekilde (Yılmaz \& Dağlıŏlu, 2003) yulaf kepeği ekleyerek hazırladıkları köftelerin $\mathrm{pH}$ sında artı̧ gözlerken, domates, pancar lifi kullanılarak hazırlanan et ürünlerinde ise 
kullanılan lifin asidik özelliğinden dolayı pH değerleirnde azalma gözlenmiştir (Cava, Ladero, Cantero, \& Rosario Ramírez, 2012). Pişme sırasında meydana gelen protein denatürasyonu, elektriksel yüklerindeki değişim ve su kaybından dolayı, genelde et ürünlerinin pH değerlerinde artış gözlenmektedir. Pişmeye bağlı pH artışı, yüksek miktarda ve büyük boyutlu lif eklenen köfteler hariç diğer tüm örneklerde gözlenmiştir.

Tablo 1. Pişirme sonrası, köftelerin ă̆ırlıkları, çaplarındaki ve pH değerlerinde değişim

\begin{tabular}{|c|c|c|c|c|c|}
\hline \multirow{2}{*}{ Lif Boyutu ( $\mu \mathrm{m})$} & \multirow{2}{*}{$\begin{array}{c}\text { Lif } \\
\text { Miktarı } \\
(\%)\end{array}$} & \multirow{2}{*}{$\begin{array}{c}\text { Ağırlık Kaybı } \\
(\%)\end{array}$} & \multirow{2}{*}{$\begin{array}{c}\text { Çap Azalması } \\
(\%)\end{array}$} & \multicolumn{2}{|c|}{ pH } \\
\hline & & & & çĭ̆ & pişmiş \\
\hline \multirow{2}{*}{150} & 0.4 & $35.14 \pm 1.23^{\mathrm{aA}}$ & $18.99 \pm 2.42^{\mathrm{aA}}$ & $5.64 \pm 0.01^{\mathrm{aAx}}$ & $6.36 \pm 0.01^{\mathrm{aAx}}$ \\
\hline & 2.4 & $25.90 \pm 1.33^{\mathrm{bAx}}$ & $16.53 \pm 2.37^{\mathrm{aA}}$ & $5.58 \pm 0.01^{\mathrm{bAx}}$ & $6.27 \pm 0.01^{\mathrm{bA}}$ \\
\hline \multirow{2}{*}{450} & 0.4 & $30.04 \pm 0.91^{\mathrm{aBx}}$ & $14.15 \pm 2.67^{\mathrm{aB}}$ & $5.35 \pm 0.01^{\mathrm{aB}}$ & $5.72 \pm 0.01^{\mathrm{aBx}}$ \\
\hline & 2.4 & $28.94 \pm 0.54^{\mathrm{aBx}}$ & $16.30 \pm 2.50^{\mathrm{aA}}$ & $6.54 \pm 0.01^{\mathrm{bBx}}$ & $6.40 \pm 0.01^{\mathrm{bBx}}$ \\
\hline Kontrol & & $35.09 \pm 1.12$ & $16.92 \pm 3.57$ & $5.38 \pm 0.01$ & $6.31 \pm 0.01$ \\
\hline
\end{tabular}

a-b, lif miktarı arası farklılıkları; A-B, lif boyutu arası farklıkları gösterir. x, kontrolden farklılığı gösterir.Herhangi bir üst simge olmaması, sonuçlar üzerinde değişkenlerin veya interaksiyonlarının etkisi olmadığını gösterir. Kontrol örneğine enginar lifi eklenmemiştir.

\subsubsection{Köfte örneklerinin renk değerlerindeki değişim}

Renk değerleri üzerine değişkenlerin, lif boyutu ve miktarının, ve interaksiyonlarının etkisi iki yollu ANOVA ile; her örneğin kontrolden farkı ise tek tollu ANOVA ile değerlendirilmiştir. İki yollu ANOVA analizi sonucunda, pişmemiş ve pişmiş köftelerin beyazlık (L) değeri üzerine boyut ve lif miktarının ve interaksiyonlarının önemi olmamıştır (Tablo 2).

Pişmemiş köftelerin kırmızılık (a) ve yeşillik (b) değerleri üzerinde, değişkenlerin kendisi ve interaksiyonlarının istatiksel açıdan etkisi olmamıştır, a değeri açısından kontrol ile karşılaştırıldıkları zaman her ne kadar düşük miktarda küçük boyutlu lif eklenerek hazırlanan köfteler hariç, diğer örneklerde a değerinde artış gözlense de, yine bu artış istatiksel olarak önemli olmamıştır ( $\mathrm{p}>0.05$ ). Pişmiş örneklerin kırmızılık (a) değeri üzerine ise, sadece lif miktarının etkisi önemli olmuş, her iki boyutta da lif miktarı arttıkça köftelerin kırmızılık değerleri azalmıştır. Benzer şekilde kontrol ile karşılaştırıldıkları zaman, aralarındaki fark önemli olmamıştır. Pişmiş örneklerin yeşillik (b) değeri üzerinde de değişkenlerin veya interaksiyonlarının etkisi önemli olmamış, benzer şekilde kontrolden de farkları olmamıştır.

Tablo 2. Farklı boyut ve miktarlarda eklenen enginar lifinin çiğ ve pişmiş köftelerin renk değerleri üzerine etkisi

\begin{tabular}{|c|c|c|c|c|c|}
\hline & & \multirow[t]{2}{*}{ Lif miktarı (\%) } & \multicolumn{2}{|c|}{ Boyut ( $\mu \mathrm{m})$} & \multirow[b]{2}{*}{ Kontrol } \\
\hline & & & 150 & 450 & \\
\hline \multirow{4}{*}{$\mathbf{L}^{*}$} & \multirow{2}{*}{ çiğ } & 0.4 & $44.48 \pm 1.21$ & $43.47 \pm 3.62$ & \multirow{2}{*}{$44.70 \pm 2.25$} \\
\hline & & 2.4 & $40.50 \pm 1.90$ & $45.35 \pm 2.18$ & \\
\hline & \multirow{2}{*}{ pişmiş } & 0.4 & $39.55 \pm 1.22$ & $37.58 \pm 1.47$ & \multirow{2}{*}{$35.88 \pm 1.70$} \\
\hline & & 2.4 & $39.21 \pm 2.2$ & $38.23 \pm 2.40$ & \\
\hline \multirow{4}{*}{$a^{*}$} & \multirow{2}{*}{ çĭ̆ } & 0.4 & $12.68 \pm 1.57$ & $13.80 \pm 1.74$ & \multirow{2}{*}{$12.64 \pm 1.12$} \\
\hline & & 2.4 & $13.42 \pm 2.70$ & $13.49 \pm 0.74$ & \\
\hline & \multirow{2}{*}{ pişmiş } & 0.4 & $8.14 \pm 0.85^{\mathrm{a}}$ & $9.32 \pm 0.88^{\mathrm{a}}$ & \multirow{2}{*}{$8.94 \pm 0.91$} \\
\hline & & 2.4 & $7.00 \pm 0.83^{\mathrm{b}}$ & $7.81 \pm 1.17^{\mathrm{b}}$ & \\
\hline \multirow{4}{*}{$b^{*}$} & \multirow{2}{*}{ çĭg } & 0.4 & $10.46 \pm 1.27$ & $11.35 \pm 1.00$ & \multirow{2}{*}{$10.54 \pm 1.48$} \\
\hline & & 2.4 & $9.87 \pm 0.23$ & $11.13 \pm 1.35$ & \\
\hline & \multirow{2}{*}{ pişmiş } & 0.4 & $6.07 \pm 0.27$ & $5.96 \pm 1.64$ & \multirow{2}{*}{$6.08 \pm 1.38$} \\
\hline & & 2.4 & $5.55 \pm 0.88$ & $6.01 \pm 0.57$ & \\
\hline
\end{tabular}

a-b, sütunlar (lif miktarı) arası farklılıkları gösterir $(\mathrm{p}<0.05)$. Herhangi bir üst simge olmaması, sonuçlar üzerinde değişkenlerin veya interaksiyonlarının etkisi olmadığını gösterir. Kontrol örneğine enginar lifi eklenmemiştir. 


\subsubsection{Köfte örneklerinin tekstürel özelliklerinde değişim}

Gıdalarda pişirme süresince protein denatürasyonuna bağlı olarak tekstürel değişiklikler gözlemlenir, yağ absorpsiyonu artar ve nem kaybı yaşanır. Bu etmenler üründe sertleşmeye ve küçülmelere sebep olmaktadır (Cava ve ark., 2012). İki yollu ANOVA sonuçlarına göre, çiğ köftelerin sertlik değeri üzerine lif miktarı ve lif miktarının boyutuyla interaksiyonu etkili olmuştur (Tablo 3). Bu sonuçlara göre, düşük boyutlu lif eklenen pişmemiş köftelerin sertlik değeri üzerinde lif miktarının etkisi yönemli değilken, büyük boyutlu lif eklenen örneklerde ise lif miktarı arttıkça sertlik değeri artmıştır ve kontrol ile sertlik açısından sadece bu örnekte farklılık gözlenmiştir. Lif boyutu artışı ile, su tutma kapasitesinin artışı bu sonucu desteklemektedir. Pişirilen köftelerde ise, değişkenlerin kendileri, interaksiyonları sonuçlar üzerinde önemli olmazken, kontrolden farklı örnek de bulunmamaktadır (Tablo 4). Yapışkanlık değeri üzerinde ise, lif miktarı ve onun lif boyutu ile olan interaksiyonu önemli olmuştur. Düşük boyutlu lif kullanımında, lif miktarı arttıkça yapışkanlık değeri azalırken, yüksek boyutlu lif kullanıldı̆̆ında lif miktarının etkisi önemli olmamıştır. Kontrol ile karşılaştııldığında, yüksek konsantrasyonda lif kullanıldığı zaman pişmemiş köftelerde yapışkanlık azalsa da, sadece düşük boyutlu lif eklenen örnekteki azalma istatiksel açıdan anlamlı olmuştur.

Köfteler pişirildiği zaman, her iki boyutta da lif miktarının artması ile yapışkanlık azalmış, her iki konsantrasyonda da daha büyük boyutlu lif eklenmesi ile yapışkanlık değeri nispeten artmıştır, ancak yapışkanlık değerleri açısından pişmiş örneklerde kontrolden farklı örnek bulunmamıştır. Lif miktarı ve boyutunun interaksiyonu pişrilmeyen köftelerin iç yapışkanlık ve sakızımsılık üzerine etkili olmuş, yüksek boyutta lif, sadece yüksek oranda eklendiğinde iç yapışkanlık değeri azalmış, sakısızmsılık değeri artmış ve bu değişimin kontrol örneğinden farkı da önemli olmuştur. Suyun daha fazla tutulması ile, daha kesikli ve dağınık bir yapı elde edilebileceğinden bu değerde azalma gözlenmiş olabilir.

Çiğnenebilirlik değeri, sertlik, esneklik ve iç yapışkanlığın fonksiyonu olduğundan dolayı, değişkenlerin interaksiyonu önemli olup, sadece yüksek lif miktarında büyük boyutlu lif eklenmesi pişirilmeyen köftelerin, çiğnenebilirlik değeri üzerinde etkili olup, kontrolden farkı önemli olmuştur. Pişirilme ile beraber, kontrolden fark ortadan kalkmış, lif eklenen örnekler arasında, yalnızca düşük boyutlu olan liflerin yüksek konsantrasyonda eklenmesiyle çiğnenebilirlikte önemli derecede azalma gözlenmiştir. Elastikiyet değerleri açısından ise, pişirilmeyen köfteler üzerinde lif miktarının ve boyutun etkisi ayrı ayrı önemli olup, interaksiyonları önemli olmamıştır. Kontrolden fark ise sadece, düşük boyutta ve yüksek konsantrasyonda lif eklenen örnekte gözlenmiştir. Örnekler pişirildiği zaman ise, kontrolden farkl1lık yüksek boyutlu lifin her iki konsantrasyonda eklendiği örneklerde öenmli olmuştur. Lif içeren örnekler kendi aralarında karşılaştırıldıkları zaman, artan lif miktarı ile elastikiyet değeri azalmıştır.

Tablo 3. Farklı boyutlarda ve farklı miktarlarda enginar lifi eklenen çiğ köftelerin tekstürel özellikleri

\begin{tabular}{|c|c|c|c|c|}
\hline & Lif miktarı (\%) & Bo & m) & \\
\hline & & 150 & 450 & Kontrol \\
\hline Sertlik & 0.4 & $4.88 \pm 0.42^{\mathrm{aA}}$ & $3.69 \pm 0.55^{\mathrm{aA}}$ & $3.97 \pm 0.30$ \\
\hline & 2.4 & $4.30 \pm 1.24^{\mathrm{aA}}$ & $6.60 \pm 0.16^{\mathrm{bBx}}$ & \\
\hline Yapışkanlık & 0.4 & $-244.26 \pm 23.60^{\mathrm{aA}}$ & $-185.63 \pm 25.87^{\mathrm{aA}}$ & $-200.95 \pm 14.83$ \\
\hline & 2.4 & $-98.06 \pm 62.64^{\mathrm{bAx}}$ & $-154.36 \pm 17.7^{\mathrm{aA}}$ & \\
\hline Esneklik & 0.4 & $0.92 \pm 0.00$ & $0.93 \pm 0.00$ & $0.92 \pm 0.00$ \\
\hline & 2.4 & $0.87 \pm 0.07$ & $0.90 \pm 0.04$ & \\
\hline İç yapışkanlık & 0.4 & $0.58 \pm 0.01^{\mathrm{aA}}$ & $0.59 \pm 0.01^{\mathrm{aA}}$ & $0.58 \pm 0.00$ \\
\hline & 2.4 & $0.58 \pm 0.08^{\mathrm{aA}}$ & $0.54 \pm 0.09^{\mathrm{bBx}}$ & \\
\hline Sakızımsılık & 0.4 & $2.83 \pm 0.24^{\mathrm{aA}}$ & $2.16 \pm 0.27^{\mathrm{aA}}$ & $2.32 \pm 0.17$ \\
\hline & 2.4 & $2.55 \pm 0.76^{\mathrm{aA}}$ & $3.55 \pm 0.03^{\mathrm{bBx}}$ & \\
\hline Çiğnenebilirlik & 0.4 & $2.62 \pm 0.22^{\mathrm{aA}}$ & $2.01 \pm 0.24^{\mathrm{aA}}$ & $2.15 \pm 0.16$ \\
\hline & 2.4 & $2.27 \pm 0.86^{\mathrm{aA}}$ & $3.22 \pm 0.17^{\mathrm{bBx}}$ & \\
\hline Elastikiyet & 0.4 & $0.16 \pm 0.00^{\mathrm{aA}}$ & $0.16 \pm 0.02^{\mathrm{aB}}$ & $0.16 \pm 0.00$ \\
\hline & 2.4 & $0.18 \pm 0.07^{\mathrm{bAx}}$ & $0.16 \pm 0.09^{\mathrm{bB}}$ & \\
\hline
\end{tabular}

$\mathrm{a}-\mathrm{b}$, satırlar (\% lif miktarı) arası farklılıkları; A-B, sütunlar (lif boyutu) arası farklıkları gösterir ( $<<0.05)$. Herhangi bir üst simge olmaması, sonuçlar üzerinde değişkenlerin veya interaksiyonlarının etkisi olmadığını gösterir. x, kontrolden farklılığı gösterir. Kontrol örneğie enginar lifi eklenmemiştir. 
Tablo 4. Farklı boyutlarda ve farkl miktarlarda enginar lifi eklenen pişmiş köftelerin tekstürel özellikleri

\begin{tabular}{|c|c|c|c|c|}
\hline & \multirow[t]{2}{*}{ Lif miktarı (\%) } & \multicolumn{2}{|c|}{ Boyut( $\mu \mathrm{m})$} & \multirow[b]{2}{*}{ Kontrol } \\
\hline & & 150 & 450 & \\
\hline \multirow{2}{*}{ Sertlik } & 0.4 & $1233.73 \pm 263.81$ & $1122.71 \pm 139.55$ & \multirow{2}{*}{$823.60 \pm 22.0$} \\
\hline & 2.4 & $747.78 \pm 215.00$ & $890.98 \pm 1.63$ & \\
\hline \multirow{2}{*}{ Yapışkanlık } & 0.4 & $-0.26 \pm 0.07^{\mathrm{aA}}$ & $-0.63 \pm 0.27^{\mathrm{aB}}$ & \multirow{2}{*}{$-0.47 \pm 0.28$} \\
\hline & 2.4 & $-0.04 \pm 0.04^{\mathrm{bA}}$ & $-0.15 \pm 0.10^{\mathrm{bB}}$ & \\
\hline \multirow{2}{*}{ Esneklik } & 0.4 & $2.45 \pm 0.06$ & $2.07 \pm 0.39$ & \multirow{2}{*}{$1.89 \pm 0.62$} \\
\hline & 2.4 & $1.70 \pm 0.70$ & $2.23 \pm 0.18$ & \\
\hline \multirow{2}{*}{ İç yapışkanlık } & 0.4 & $0.90 \pm 0.00^{\mathrm{a}}$ & $0.92 \pm 0.00^{\mathrm{ax}}$ & \multirow{2}{*}{$0.87 \pm 0.00$} \\
\hline & 2.4 & $0.87 \pm 0.04^{\mathrm{b}}$ & $0.88 \pm 0.00^{\mathrm{b}}$ & \\
\hline \multirow{2}{*}{ Sakızımsılık } & 0.4 & $945.17 \pm 335.83$ & $939.49 \pm 181.49$ & \multirow{2}{*}{$712.55 \pm 23.57$} \\
\hline & 2.4 & $640.25 \pm 157.88$ & $786.67 \pm 1.77$ & \\
\hline \multirow{2}{*}{ Çiğnnenebilirlik } & 0.4 & $2340.70 \pm 881.06^{\mathrm{a}}$ & $1878.95 \pm 2.84^{\mathrm{a}}$ & \multirow{2}{*}{$1358.71 \pm 492.97$} \\
\hline & 2.4 & $976.79 \pm 179.80^{\mathrm{b}}$ & $1755.60 \pm 147.40^{\mathrm{a}}$ & \\
\hline \multirow{2}{*}{ Elastikiyet } & 0.4 & $0.53 \pm 0.01^{\mathrm{aA}}$ & $0.54 \pm 0.00^{\mathrm{aBx}}$ & \multirow{2}{*}{$0.51 \pm 0.00$} \\
\hline & 2.4 & $0.52 \pm 0.00^{\mathrm{bA}}$ & $0.48 \pm 0.05^{\mathrm{bBx}}$ & \\
\hline
\end{tabular}

a-b, satırlar (lif miktarı,\%) arası farklılıkları; A-B, sütunlar (lif boyutu) arası farklıkları gösterir ( $<<0.05)$. Herhangi bir üst simge olmaması, sonuçlar üzerinde değişkenlerin veya interaksiyonlarının etkisi olmadığını gösterir. x, kontrolden farklılığı gösterir. Kontrol örneğie enginar lifi eklenmemiştir.

\subsubsection{Köfte örneklerinin duyusal özelliklerinde değişim}

Duyusal özellikler açısından sadece renk üzerine olan etkide, her iki lif boyutunda da, köftelere eklenen lif miktarı arttıkça renk değerinde azalma olduğu gözlenmiştir. Kontrol köftesinden fark ise, enginar lifinin daha büyük boyutlu ve daha yüksek konsantrasyonda eklendiği örnekte istatiksel olarak anlamlı olmuştur. Sululuk açısından değerlendirildiği zaman, her iki boyutta da lifin daha yüksek konsantrasyonlarda eklendiği örneklerde bu değer azalmış ancak fark istatiksel olarak anlamlı olmmaıştır. Benzer şekilde çiğnenebilirlik ve genel beğeni açısından da en az puan alan örnek lifin büyük boyutta ve yüksek konsantrasyonda eklendiği örnek olmuştur. (Tablo 5).

Tablo 5. Farklı boyutlarda ve farklı miktarlarda enginar lifi eklenen pişmiş köftelerin duyusal özellikleri

\begin{tabular}{|c|c|c|c|c|}
\hline & \multirow[t]{2}{*}{ Lif miktarı (\%) } & \multicolumn{2}{|c|}{ Boyut $(\mu \mathrm{m})$} & \multirow[b]{2}{*}{ Kontrol } \\
\hline & & 150 & 450 & \\
\hline \multirow[b]{2}{*}{ Renk } & 0.4 & $3.7 \pm 0.82^{\mathrm{a}}$ & $4.1 \pm 0.88^{\mathrm{a}}$ & \multirow[b]{2}{*}{$4.3 \pm 0.67$} \\
\hline & 2.4 & $3.4 \pm 0.70^{\mathrm{b}}$ & $3.3 \pm 0.67^{\mathrm{bx}}$ & \\
\hline \multirow{3}{*}{ Koku } & 0.4 & $3.6 \pm 0.84$ & $3.9 \pm 0.99$ & \multirow{2}{*}{$3.9 \pm 0.88$} \\
\hline & 2.4 & $3.6 \pm 0.97$ & $3.5 \pm 0.71$ & \\
\hline & 0.4 & $3.2 \pm 1.03$ & $3.5 \pm 0.97$ & \multirow[b]{2}{*}{$3.5 \pm 0.71$} \\
\hline Sululuk & 2.4 & $2.9 \pm 1.10$ & $2.8 \pm 0.92$ & \\
\hline \multirow{3}{*}{ Sertlik } & 0.4 & $3.3 \pm 0.95$ & $3.6 \pm 0.97$ & \multirow{3}{*}{$3.5 \pm 0.85$} \\
\hline & 2.4 & $3.0 \pm 0.94$ & $2.8 \pm 1.03$ & \\
\hline & 0.4 & $3.6 \pm 0.84$ & $3.7 \pm 0.95$ & \\
\hline Tat ve Aroma & 2.4 & $3.1 \pm 0.99$ & $3.0 \pm 0.94$ & \multirow[t]{2}{*}{$3.5 \pm 0.71$} \\
\hline \multirow[b]{2}{*}{ Çiğnenebilirlik } & 0.4 & $3.3 \pm 1.16$ & $3.5 \pm 0.85$ & \\
\hline & 2.4 & $3.1 \pm 0.88$ & $2.6 \pm 0.84$ & \multirow[t]{2}{*}{$3.4 \pm 0.70$} \\
\hline \multirow[b]{2}{*}{ Genel Beğeni } & 0.4 & $3.3 \pm 1.16$ & $3.8 \pm 0.92$ & \\
\hline & 2.4 & $3.1 \pm 0.88$ & $2.8 \pm 0.92$ & $3.7 \pm 0.95$ \\
\hline
\end{tabular}

$\mathrm{a}-\mathrm{b}$, satırlar (lif miktarı,\%) arası farklılıkları gösterir $(\mathrm{p}<0.05)$. Herhangi bir üst simge olmaması, sonuçlar üzerinde değişkenlerin veya interaksiyonlarının etkisi olmadığını gösterir. x, kontrolden farklılığı gösterir. Kontrol örneğine enginar lifi eklenmemiştir.

\section{Sonuç}

Enginar atıklarından elde edilen liflerin boyutlarındaki azalma ile beraber su bağlama ve yağ tutma kapasitelerinde azalma gözlenmiştir. Pişirme sonrası köftelerde görülen ağırlık kaybındaki azalma üzerine eklenen lif miktarının etkisi, lifin boyutuna göre farklılık göstermiştir. Eklenen lifin miktarı yüksek boyutlu liflerde önemli olmazken, düşük boyutlu liflerde lifin miktarı arttıkça ağırlık kaybında daha az azalma olmuştur. Lif eklenmeyen örnekle karışılaştırıldığı zaman ise, lif eklenen örneklerde genel olarak ağırlık 
kaybının daha az olduğu gözlenmiştir. Çaptaki azalmanın en az olduğu örnek, yüksek boyutta ve düşük konsantrasyonda lif eklenen örnek olmuştur. Bu iki değer göz önüne alındığı zaman, yüksek boyutlu lifin düşük konsantrasyonda köfte formülasyonunda kullanılması önerilebilir. Renk değerleri açısından, sadece kırmızılık değeri üzerine lif miktarının etkisi önemli olurken, kontrol köfteler ile aralarındaki fark önemli olmamıştır. Tüm duyusal değerlendirmeler açısından kontrol örneğine en yakın sonuçları, enginar lifinin düşük konsantrasyonda ancak büyük boyutta eklendiği örnek almıştır. Sonuç olarak, enginar lifinin köfte formülasyonunda kullanımı hakkında şu öneriler yapılabilir:

1. Çalışmada köfte örneklerinin verimi (ağırlık ve çapta azalma) göz önüne alındığında, sadece eklenen lifin miktarının değil, aynı zamanda boyutunun da sonuçlar açısından önemli olduğu görülmüştür

2. Diyet liflerinin sağlık açısından faydaları ve et ürünlerindeki olumlu etkileri göz önüne alındığında köfte gibi et ürünlerinde tekstürel ve duyusal açısından kontrole göre farklılıklar çıkmamıştır, bu nedenle et ürünlerinde kullanımı yaygınlaştırılabilir

\section{Kaynakça}

Cava, R., Ladero, L., Cantero, V., \& Rosario Ramírez, M. (2012). Assessment of Different Dietary Fibers (Tomato Fiber, Beet Root Fiber, and Inulin) for the Manufacture of Chopped Cooked Chicken Products. Journal of Food Science, 77(4), C346-C352. https://doi.org/10.1111/j.1750-3841.2011.02597.x

Choi, Y.S., Choi, J.H., Han, D.J., Kim, H.Y., Lee, M.A., Jeong, J.Y., Chung, H.J. \& Kim, C.J., (2010). "Effects of replacing pork back fat with vegetable oils and rice bran fiber on the quality of reduced-fat frankfurters", Meat Sci., 84:557-563. https://doi.org/10.1016/j.meatsci.2009.10.012

Elleuch, M., Bedigian, D., Roiseux, O., Besbes, S., Blecker, C. \& Attia, H., (2011). "Dietary fibre and fibre-rich by-products of food processing: Characterisation, technological functionality and commercial applications: A review", Food Chem., 124:411-421. https://doi.org/10.1016/j.foodchem.2010.06.077

Ekici, L., \& Ercoşkun, H. (2007). Et Ürünlerinde Diyet Lifi Kullanımı. GTED. 1:83-90

Encalada, A.M.I., Basanta, M.F., Fissore, E.N., De'Nobili, M.D., \& Rojas, A.M. (2015). Carrot fiber (CF) composite films for antioxidant preservation: particle size effect, CarbohydratePolymers, http://dx.doi.org/10.1016/j.carbpol.2015.09.109

Fernandez-Lopez, J., Sanchez-Zapata, E., Munoz, C.M., Fuentes, E., Sendra, E., Sayas, E., Navarro, C. \& Perez-Alvarez, J.A., (2010). "Effect of tiger nut fibre on quality characteristics of pork burger", Meat Sci., 85:7076.https://doi.org/10.1016/j.meatsci.2009.12.006

Han, M., \& Bertram H. C. (2017). Designing healthier comminuted meat products: Effect of dietary fibers on water distribution and texture of a fat-reduced meat model system. Meat Science. 133:159- 165. http://dx.doi.org/10.1016/j.meatsci.2017.07.001.

Hellwege, E.M., Czapla, S., Jahnke, A., Willmitzer, L. \& Heyer, A.G., (2000). "Transgenic potato (Solanum tuberosum) tubers synthesize the full spectrum of inülin molecules naturally occurring in globe artichoke (Cynara scolymus) roots", Proceedings of the National Academy of Sciences, 97:8699-8704. https://doi.org/10.1073/pnas.150043797

Henning, S. S. C., Tshalibe, P., \& Hoffman, L. C. (2016). Physico-chemical properties of reduced-fat beef species sausage with pork back fat replaced by pineapple dietary fibres and water. LWT, 74, 92-98. https://doi.org/https://doi.org/10.1016/j.lwt.2016.07.007

Ktari, N., Smaoui, S., Trabelsi, I., Nasri, M., \& Ben Salah, R. (2014). Chemical composition, techno-functional and sensory properties and effects of three dietary fibers on the quality characteristics of Tunisian beef sausage. Meat Science, 96(1), 521-525. https://doi.org/https://doi.org/10.1016/j.meatsci.2013.07.038

Kılınççeker, O., \& Kurt, Ş. (2018). Effects of inulin, carrot and cellulose fibres on the properties of raw and fried chicken meatballs. South African Journal of Animal Science, 48 (1). http://dx.doi.org/10.4314/sajas.v48i1.5

Machado, M. T. C., Eça, K. S. Vieira, G. S., Menegalli, F. C., Martínez, J., \& Hubinger, M.D. (2015). Prebiotic oligosaccharides from artichoke industrial waste: evaluation of different extraction methods. Industrial Crops and Products,76, 141-148. http://dx.doi.org/10.1016/j.indcrop.2015.06.047

Premavalli, K. S. (2010). Effect of particle size reduction on physicochemical properties of ashgourd (Benincasa hispida) and radish (Raphanus sativus) fibres AU - Gupta, Prachi. International Journal of Food Sciences and Nutrition, 61(1), 18-28. https://doi.org/10.3109/09637480903222186

Talukder, S. (2015). Effect of Dietary Fiber on Properties and Acceptance of Meat Products: A Review AU - Talukder, Suman. Critical Reviews in Food Science and Nutrition, 55(7), 1005-1011. https://doi.org/10.1080/10408398.2012.682230

Tomaschunas, M., Zörb, R., Fischer, J., Köhn, E., Hinrichs, J., \& Busch-Stockfisch, M. (2013). Changes in sensory properties and consumer acceptance of reduced fat pork Lyon-style and liver sausages containing inulin and citrus fiber as fat replacers. Meat Science, 95(3), 629-640. https://doi.org/https://doi.org/10.1016/j.meatsci.2013.06.002

Verma, A., K., \& Banerjee, R. (2010). Dietary fibre as functional ingredient in meat products: a novel approach for healthy living - a review. Journal of Food Science and Technology. 47(3), 247-257.doi:10.1007/s13197-010-0039-8

Ye, F., Tao, B., Liu, J., Zou, Y., \& Zhao, G. (2015). Effect of micronization on the physicochemical properties of insoluble dietary fiber from citrus (Citrus junos Sieb. ex Tanaka) pomace. Food Science and Technology International, 22(3), 246-255. https://doi.org/10.1177/1082013215593394

Yılmaz, İ., \& Dağlığlu, O. (2003). The effect of replacing fat with oat bran on fatty acid composition and physicochemical properties of meatballs. Meat Science, 65(2), 819-823. https://doi.org/https://doi.org/10.1016/S0309-1740(02)00286-3

Zhang, Z., Song, H., Peng, Z., Luo, Q., Ming, J., \& Zhao, G. (2012). Characterization of stipe and cap powders of mushroom (Lentinus edodes) prepared by different grinding methods. Journal of Food Engineering, 109(3), 406-413. https://doi.org/https://doi.org/10.1016/j.jfoodeng.2011.11.007 